\title{
Research on Chinese national music based on the perspective of Musical Anthropology
}

\author{
Xiaoyan Liu \\ College of music, China West Normal University, Nanchong Sichuan, 637009, China
}

Keywords: Music anthropology, National music, Development ideas

\begin{abstract}
The folk music has always been the most important treasure in the treasure house of the Chinese music. Till now it has been five thousand years .After music anthropology has entered into our country, it has been continuously developed. The communication between Chinese national music and other countries has become more and more. In this process, music anthropology has promoted the development of national music in China. Therefore, it is important to explore the development of Chinese national music on the basis of musical anthropology, which is very important for the development of our national music industry. The music anthropology was elaborated;the development history of our country's music anthropology was reviewed, and the Chinese national music development thought based on the music anthropology was discussed .
\end{abstract}

\section{Introduction}

With the rapid development of music anthropology in China tends to be mature, it has entered into the whole field of China's local music research. While ,our country's music anthropology has become one of the most important part of the global music anthropology system. Our country's music anthropology practice has tended to the depth and the maturity. The splendid Chinese civilization has accumulated a very rich historical precipitation, thus providing a new opportunity for the development of Chinese national music. National music as the center of Chinese music culture, has a very large value. In recent years, the research on the related content of Chinese national music has become more and more deeply. The communication between Chinese national music and global music is becoming more and more frequent. This will be more need to be studied under the guidance of the theory of musical anthropology, which will promote the development of Chinese national music.

\section{Musical anthropology}

Music anthropology, also known as national music, is a cross discipline between two subjects, such as music and cultural anthropology, which aims at studying the specific behavior of human beings. The study of the original text from the beginning of the original society to the non mainstream folk characteristics of music, and then extended to all of the human music culture phenomenon of deep concern. That is to say, this subject not only to study the relationship between music and culture, but also to explore the influence of human behavior and music performance.Regard music as a culture to show its important value in the survival and development of human beings. The diversity of music is determined by the nationality of the music. China is a country with a large number of people, and its national culture also shows a variety of aspects, which requires the national music must have a variety of. The geography, humanities and customs of all nationalities in China have a very strong and unique national characteristics, and the form of national music has very strong and changeable characteristics. Music plays an important role in the Chinese national culture. It is a very important element of the national character, which represents the important characteristic of the Chinese nation, and it is an important form of Chinese national culture. Music and the overall national culture is a very complex and diverse and closely linked, fully reflected in the national music, dance and character, and many other aspects. Due to the specific practice and development of music anthropology in china.

As for the anthropological' $\mathrm{s}$ opinion, the music is actually a reflection of the subject consciousness of human being. Because of the continuous development of society and the rapid 
development of culture, music has become an important part of modern life. The emergence and development of the music has a very distinct characteristics of the times, in different historical periods and different ethnic regions, because the cultural background and customs vary, music in the characteristics, content and form of the external have considerable differences. Regarding to the concept, the content of the research of musical anthropology includes the origin, the background, the function and the function of the music in the process of social development. At the same time, the content of music anthropology covers the traditional folk music, oral music and other forms. There is a very rich cultural connotation in China's national music.China's national music is relatively independent, in its development process each penetration, with a very strong uniqueness and diversity. In the study of the traditional folk music, Chinese music anthropology research is based on the special historical accumulation and cultural heritage of the national culture, and in the implementation of equal communication, can support each other and progress together, expanding the field of China's national music, and thus promoting the harmony between China's national music and western developed countries.

\section{The development of music anthropology in China}

As early as 1916, China's traditional music and music history expert Xiao Youmei implement targeted comparative analysis on China and the western countries . There was very strong sense of national pride and strong feelings in many of his national music related papers . Subsequently, China's famous national music research expert Wang Guangqi consider the perspective of music anthropology, comparative study and explore the same points and differences between Chinese and western music . After his communication, forming a very rich experience for the development of music anthropology in China. Because of the deep practice and continuous development of music anthropology in China, the Chinese national music has a very strong national culture and emotion. Along with our country's deep research and the cognition to the national music in the continuous and the thorough development, the Chinese music anthropology research already obtained the extremely swift and violent development. Today, the concept of music anthropology is blended with national music . The research method in the field of research has been very good use, this way, to a considerable extent, expand and enrich the perspective of Chinese music researchers, there are more and more domestic and foreign researchers have applied more scientific, more standardized research tools to explore the traditional Chinese national music. Based on the mutual exchange and mutual promotion between the national music and the world, the theory of human music in China is becoming more and more modern.

\section{Development ideas of China's national music based on the music anthropology}

The development of Chinese national culture and national music. China is a large country with many nationalities. It has a diversity of culture, with more and more rich historical and cultural connotation, and more abundant national culture form, which has decided the diversity of Chinese culture in content and form. With the development of international cultural exchanges, China's national culture is increasingly influenced by foreign culture. From the beginning of the Wei, Jin, southern and Northern Dynasties, Buddhist culture began to spread and develop continuously in China, which deeply influenced the development of Chinese culture. From the beginning of our country's five four movement, many Western civilization have poured into our country, which has influenced the Chinese culture trend to modernization. To the second half of the last century, was deeply influenced by the western culture, Chinese culture also show diversity, openness and promote of characteristics. In our country, the Chinese national culture has been developed, and the music has become a very important link between different nations. In the research and practice of music anthropology in our country, we should use the method of musical anthropology, so that human beings can communicate with the way of music. As a result, the cultural background of our country shows a very strong diversity, so as to promote the music anthropology in our country's national music in the field of practice and development, this way, it should be based on the national traditional 
sense of human habits and cultural development. All the music and human scholars in our country actively promote the cultural background of different nations and the relationship between the music and culture. They feel and music activities closely related to the characters as well as the way of behavior, content and other important reference standards for national music. It is more advantageous for the study of music anthropology that the national music and China have a long history of national culture to implement more organic connection and combination, which is more conducive to the study of the subject of music anthropology.

Analysis of the differences between Chinese national music. China's national music has a very strong regional characteristics, for minority music, according to the different communities of different nationalities, can be divided into northeast, northwest, southwest, South and southeast of four different area. The language, culture and customs of our country have a very big difference, which will lead to the uniqueness and difference of Chinese local and national music., for example, has always been the Yanzhao the call of Hebei Province, the terrain is very vast, its history and culture is also very long, is also our country culture of the Chinese nation is a very important birthplace. The folk art in our country in the form, in the form of diversity. Our country has a long history and splendid history civilization and a very rich human feelings. For example, in China's Hebei Sheng and wind music, Tangshan area of Pingju opera and Hebei Bangzi, together constitute the very rich and colorful and diversified forms of music culture. The Pingju opera is called tangshanluo $\mathrm{Zi}$ or the Bengbeng play, is through the development of Lianhualao, belongs to the traditional sense of singing art. A lot of it is popular in Peking opera libretto and easy to understand, has very strong folk flavor. Leting drum from Leting County, mainly by wooden drum to be developed and evolved. Leting drum concentrated Chinese ancient many singing art form, and absorbed the essence of Leting folk. In the long period of national music singing practice and development become more and more mature. Leting drum are important and Pingju opera art form in Hebei Tangshan area. Although the same is in Tangshan Hebei area, but its artistic features and artistic forms have a considerable difference, which is often because of the diversity of the culture in Tangshan, Hebei. Differences in customs, and economic development in areas such as multivariate culture formation and development all over the world and, thus leading to the with very large differences in the way of artistic expression.

China's diversified ethnic music and its development in the field of Music Anthropology. From the perspective of musical anthropology, the Chinese national music is a very important way to promote and complement each other's culture. Communicating through music, we can actively promote the different regions, ethnic groups, as well as the different cultures of people to communicate with each other, so that we can promote the development of national culture and the common development of a variety of cultures. In the field of music anthropology, we should continue to develop national music, we need to strengthen the discipline construction of the music anthropology, and broaden the scope of the study, and actively adjust and improve the academic ideas and improve the academic level, so as to be able to cultivate more outstanding academic talents. At the same time, we should strengthen the research on the rules of the different national music, and use more scientific research methods to further promote the development of Chinese national music. At the same time, we should strengthen and expand mutual exchanges between the international research community, so as to promote the development of music anthropology in China. In view of this, we should study the Chinese national music in the scope of the musical anthropology, which inevitably will encounter different subjects, different researchers, different government, different media and different cultural industries have different values. In order to be able to inherit and carry forward our national music, not only to effectively reduce or eliminate these contradictions, which requires from music anthropology perspective to maintain and develop the national music features, so as to effectively eliminate the westernized values tendency of Chinese national culture.

\section{Conclusion}

In general, in view of the popularization and application of music anthropology in the field of Chinese folk music, it has made new progress in our country's national music in thought and theory, and it has been perfected and improved. Twentieth Century is the national music of our country to 
explore from the main emotion as the main body to carry out the music research as the main body of the new period, the process is actually a rational research and the creation of new disciplines. The national music of our country is not only a kind of culture form which originates from the ancient civilization, but also is a kind of cultural form of continuous change. There are five thousand years of rich historical and cultural connotation in our country, it has produced a very rich national music resources. The continuous development of the national culture has promoted the development of our national culture. The national music in our country has become the treasure in the treasure house of the world. In order to show our national culture plays an important position in the world, we must to multiple culture as the foundation, through in-depth excavation and protection, to promote music anthropology to achieve better development, Chinese folk music to enable them to achieve better development.

\section{References}

[1] Song Jin. Conflict and choice: different value position in music anthropology research. The art of music, 2009 (1).

[2] Xing Yanyan. Study on the national consciousness and the development of Chinese national music. Journal of Guizhou University (Art Edition), 2010 (3).

[3] Ma Guang .Study on the status of the Chinese national music in the world of multi - National Music. times literature, 2010 (11).

[4] Tian Yuying ;Zhang Xiaosheng. Inheritance and integration - the thought of rheology and evolution of traditional Chinese national music in contemporary society. Legal system and society, $2010(21)$.

[5] Zhang Yanli. Music anthropology's experience in China -- Comment on Qin Luo series "the Anthropology of music theory and method of introduction ". Music and arts, 2011 (3).

[6] Xue Yibing. Through the field into history -- study on the history of Chinese music anthropology ways and methods. Music art, 2012 (1). 